\title{
THE HISTORICAL MEMORY OF THE 1812 WAR IN LITHUANIA IN THE 19TH AND EARLY 20TH CENTURIES: A COMPLEX PROCESS
}

\author{
Virgilijus Pugačiauskas, Olga Mastianica-Stankevič \\ (Lithuanian Institute of History)
}

\begin{abstract}
In historiography, significant attention to the memory culture of the Napoleonic Wars in Europe focuses on issues relating to the memory culture of the Franco-Russian War of 1812; however, the case of Lithuania is not commonly analysed separately, thus this article discusses how assessments of the 1812 war were maintained in the historical memory in Lithuania.

The Russian government offered the population in the lands of the former GDL its official version of the historical memory of the 1812 war (of a heroic battle against an invader), which contradicted the version this population considered as 'its own', experienced as their support for Napoleon and the new political and social prospects they believed he would bring. The Russian government's censorship of written literature suppressed the spread of the people's 'own' local historical memory, yet it did not prove to be so effective due to the population's very limited opportunities to use the printed word. Communicative memory dominated in the land in the first half of the 19th century, becoming the main source testifying to and passing on to subsequent generations the actual multifaceted experiences of the $1812 \mathrm{war}$, including the chance of liberation from the yoke of the Russian Empire.

In the second half of the 19th century, representatives of local Russian imperial government structures and the local Russian intelligentsia, responding to the 1812 war as a Polish struggle for freedom and a symbol of political independence, explained in academic, educational and popular literature that the hopes of the Poles related to Napoleon were actually unfounded: the French emperor had no intentions of restoring the former Polish-Lithuanian Commonwealth within its historical boundaries, but simply wanted to fill his army units with Polish forces. It was highlighted that this expression of Polish support for Napoleon stopped the Russian imperial government's potential plans to restore the Poles' former statehood. This so-called regional narrative which appeared in history textbooks and was used by exacting emotional and visual impact in order to influence the political and cultural provisions of the younger generation had a dual purpose. First, to justify the discriminatory policies against individuals of 'Polish origins.' Second, to 'block' the path for using the 1812 war as a historical argument testifying not just to the common historical past and struggle of Poles and Lithuanians
\end{abstract}


but also their possible political future, which was openly expressed in the Polish national discourse of the early 2oth century.

Over the course of a hundred years, despite the government's actions, Poles managed to uphold 'their own' historical memory about the 1812 war; its meanings were spread in various forms of media such as fictional literature, museum exhibitions and history textbooks, and were used to shape the political and cultural position of the younger generation. In the Lithuanian national discourse on the other hand, the 1812 war, along with the 1830-1831 and 1863-1864 uprisings, was viewed as a matter concerning the Poles and the Polonised nobility, and it was thus a foreign place of historical memory. The 1812 war and assessments of its potential importance to Lithuanians in the Lithuanian national discourse of the early 2oth century were one-off cases and fragmented, while their spread among broader layers of society was limited.

KEYWORDS: the 1812 war, historical memory, Russian Empire, Lithuania, political and national discourses.

\section{Introduction}

The year 1812 during the Napoleonic Wars in Lithuania (attention is paid mostly to the borders of the Vilnius and Kaunas provinces) can be viewed as a short-term but extraordinary event that left a distinct mark on the memory of society, because political, socioeconomic and cultural life was disrupted, and because just about every member of society was, if not a participant, then at least a passive observer of these changes, regardless of their age or class. This is how Gabrielè Giunterytė-Puzinienè, a witness to these events, defined the perspective of the historical memory of this period in her memoirs:

1812 remained in one's memory for a very long time, it became a part of our conversations and a part of almost every family. Our new generation was raised on stories about 1812, as this time, like a goddess with two different faces, had a beginning, excellent and full of hope, and an end, as sad as disillusion [...] This year was special for all of Europe, for our land it meant an entire epoch, and it came up in our conversations often, like that one song often sung around a camp-fire. ${ }^{1}$

In memory culture concerning the Napoleonic Wars in historiography, significant attention is given to memory culture issues of

${ }^{1}$ G. Puzynina, W Wilnie i $w$ dworach Litewskich: pamiętnik $z$ lat 1815-1843 (Wilno, 1928), pp. 1-2. 
the 1812 war between France and Russia. The most striking example is a collection of articles that appeared in 2017, Die Napoleonischen Kriege in der europäischen Erinnerung [The Napoleonic Wars in European Memory Sites], where the memory culture of the 1812 war and memory politics are analysed through the dimensions of time and space, that is, how groups in society in different historical periods and in different regions upheld and changed memory culture meanings. ${ }^{2}$ According to the editors of that collection of articles, this approach allows us to distinguish not only specific (regional) interpretations of the $\mathbf{1 8 1 2}$ war, but also to take note of common cultural, social and political assessment models of the war, and the most typical memory culture practices. ${ }^{3}$ The anthology covers memory culture studies on the 1812 war conducted in Russia and Poland, but the case of Lithuania is not analysed.

Studies on historical memory by Russian historians also ignore the historical memory practices of the population of the former Russian Empire that testify to specific trajectories of development. ${ }^{4}$ Several attempts to look at the development of the historical memory of the Russian Empire, as opposed to the Russian nation, have been carried out; for example, the historian Evgenija Nazarova stated that the Russian government tried to form a historical memory common to all the empire's inhabitants, and that the Latvians' historical memory (according to an analysis of publications) differed to that of Russians in the province, as for them it was not a war against an enemy, but merely an episode in

${ }^{2}$ Die Napoleonischen Kriege in der europäischen Erinnerung, hg. C. Klausing, V. von Wiczlinski (Biefeld, 2017). Note that research was conducted for the 2013-2019 series 'Die Revolutions-und Napoleonishen Kriege in der europäischen Erinnerung' about the memory culture of the Napoleonic Wars in the German lands, Great Britain, Ireland and Poland.

${ }^{3}$ C. Klausing, V. von Wiczlinski, 'Kollektives Gedächtnis oder kollektives Vergessen? Perspektiven der Geschichts- und Erinnerungskultur zum Zeitalter der Napoleonischen Kriege', in: Die Napoleonischen Kriege in der europäischen Erinnering, p. 18.

${ }^{4}$ T. Saburova, "The Patriotic War of 1812 in the Commemorative Practices and Historical Memory of Russian Society from the Nineteenth to the Early TwentyFirst Centuries', in: Russia and the Napoleonic Wars (War, Culture and Society, 1750-1850), eds. J.M. Hartley, P. Keenan, D. Lieven (2015), pp. 243-257; A. Bulganov, M. Vandalkovskaia, L. Sidorova, A. Sokolova, Istoricheskaia pamiat russkogo naroda ob Otechestvennoi voinie 1812 goda (Tula, 2012). 
the war unfolding on their territory. ${ }^{5}$ Yulia Mikhailova continued researching the formation of the common historical memory of the inhabitants of the Russian Empire in territories populated by Latvians, and highlighted that Baltic Germans who published historical works in German and Latvian played an influential role in this process. In her opinion, at the beginning of the 2oth century, the local story of the Latvians' 'own' war against Napoleon was brought into the foreground, and a regional narrative was formed which analysed the relationship between peace, the daily life of Latvian peasants forced into enduring hardship, and their interaction with the occupying forces and the local authorities. ${ }^{6}$

A large number of works have been devoted to the memory culture of the 1812 war in Polish historiography. However, they are dominated by an analysis of memory culture meanings in historical works and fiction; there are some that summarise memory culture studies; however, assessments of the 1812 war made by Poles originating from the lands of the former Grand Duchy of Lithuania (GDL) are not discussed separately. ${ }^{7}$

Thus, the purpose of this article is to analyse how assessments of the 1812 war were treated in the historical memory in Lithuania.

\section{Two historical memories: a regional feature}

It could be said that the historical memory process was characterised by a specific feature, as the war of 1812 between France and Russia was a period during which the population in the territory

${ }^{5}$ E. Nazarova, 'Chtenie dlia latyshei o voinie 1812 g. XIX - nachalo XX vv.', in: Rossiia i Baltiia, vyp. 7: Pamiatnyie daty i istoricheskaia pamiat (Moskva, 2015), pp. 81-107.

${ }^{6}$ Y. Mikhailova, 'Formirovanie istoricheskoi pamiati o voinie $1812 \mathrm{~g}$. u latyshei v seredine XIX - nachale XX vv., in: Elektronnyi nauchno-obrazovatelnyi zhurnal „Istoriia“, vypusk 4 (90) (2020).

${ }^{7}$ Cf. see: A. Zahorski, Spór o Napoleona we Francji i w Polsce (Warszawa, 1974); A. Pochodaj, Legenda Napaleona I Bonaparte w kulturze polskiego romantyzmu (Wrocław, 2002); R. Leiserowitz, 'Heldenhaften Zeiten. Die polnische Erinnerungen an die Revolutions-und Napoleonischen Kriege 1815-1945', in: Band 4: Die Revolutions-und Napoleonishen Kriege in der europäischen Erinnerung (Biefeld, 2017); C. Schimscheimer, 'Ein Beispiel gab uns Bonaparte?" Die Napoleonische Kriege in der kolektiven Erinnerung der Polen', in: Die Napoleonishe Kriege in der europaischen Erinnerung, pp. $65^{-101 .}$ 
of the former Grand Duchy of Lithuania, obviously, primarily the nobles, demonstrated anti-Russian feelings, and made clear their pro-Napoleon position, associating it with the hope of resurrecting the no-longer existent state. Russia's victory in the war meant that the historical memory of the inhabitants of this land could not be expressed freely. ${ }^{8}$ Russian government institutions tried to stop news about Napoleon's intentions regarding the resurrection of the Polish-Lithuanian Commonwealth and the Grand Duchy of Lithuania from reaching the public space, or about the local population's pro-French and patriotic feelings, the circumstances under which institutions of the Lithuanian Provisional Government operated, and other information that was counter to the official position. Only news testifying to Russia's heroic struggle against the conquerer was allowed to circulate freely in the public space.

When we talk about the historical memory, it is necessary to stress that for the population of the former Grand Duchy of Lithuania, the time of the 1812 war was mostly associated not just with the chance of reinstating statehood, but with the changes to daily life brought on by the war, and the hope of seeing serfdom abolished. Even before the war, they would receive news from Užnemunè region, which belonged to the Duchy of Warsaw, about the declaration of personal liberty, and in turn rumours circulated that Napoleon had made a similar declaration in Lithuania. ${ }^{9}$ The Vilnius governor-general Alexander Rimsky-Korsakov received intelligence information from the Memel police chief that in Samogitia, the Catholic clergy were not talking about defeating the French, but were making announcements about how the French liberated them from all kinds of work..$^{10}$

What types of practices for pushing the historical memory 'into oblivion' existed? The Russian government held a monopoly on the spread of information, and engaged in censorship in order to

${ }^{8}$ T. Saburova, 'The Patriotic War of 1812 in the Commemorative Practices ...'

${ }^{9}$ B. Dundulis, Napoléon et la Lituanie en 1812 (Paris, 1940), pp. 178, 297; idem, Lietuva Napoleono agresijos metais Lietuvoje (Vilnius, 1981), pp. 75-76, 81-83.

${ }^{10}$ Akty i dokumenty arkhiva Vilenskogo, Kovenskogo i Grodnenskogo general-gubernatorskogo upravleniia, otnosiashchiesia k istorii 1812-1813 gg. Chast vtoraia. Perepiska po chasti grazdanskogo upravleniia (Vilna, 1912), p. 167. 
control the printed material published in the state and in publications being brought in from outside its borders. The censorship agency was charged with the task of not allowing historical events in which Russia was viewed as an enemy to be remembered in the public space. ${ }^{11}$ Censorship administrators tried to eliminate even the slightest reference in texts to Napoleon and the Grande Armée as liberators in Lithuania, and facts testifying to the disloyal behaviour of subjects of the Russian Empire. For this reason, only texts reflecting the official government position could dominate in the press and other literature, so it is most likely no accident that the poet Dionizas Poška glorified the honour of Alexander I against the 'Frankish enemy' in a poem, and in another of his works stated that the enemy army arrived in $1812 .{ }^{12}$ In 1824 , a collection of poetry by the writer and priest Antanas Strazdas was banned from being printed, because the censor deemed the poem 'Giesmè apie 1812 metu revoliuciją' (Hymn about the 1812 Revolution) as 'not in line with the government spirit'. This work has not survived, so we cannot determine what specific ideas of the author provoked such a strict assessment. ${ }^{13}$

It should be said that the censors' control was not universal. The book Źemajcziu Wiskupiste by Motiejus Valančius, the Bishop of Samogitia, published in 1848 , stated that Samogitia practically escaped damage during the war, as the French paid for everything by cash or by cheque, and paid generously for food. The book was banned in 1865 for its unfavourable assessment of historical facts, and for mentioning other things that did not correlate with the government's positions. ${ }^{14}$ Regardless of the efforts of the censorship institution, news about Napoleon continued to circulate in writing around the country. For example, Mykolas Römeris (in 1812 he held the position of mayor of the Vilnius municipality) ordered Napoleon's memoirs from the Zawadski bookstore in Vilnius,

${ }^{11}$ Z. Medišauskienè, Rusijos cenzūra Lietuvoje XIX a. viduryje (Kaunas, 1998), pp. 272, 277-278.

${ }^{12}$ D. Poška, Raštai (Vilnius, 1959), pp. 79, $5^{29}$.

${ }^{13}$ B. Speičyte, Strazdas, http://www.xn--altiniai-4wb.info/index/details/1086; V. Vanagas, Antanas Strazdas (Vilnius, 1968), p. 8o.

${ }^{14}$ Z. Medišauskienè, Rusijos cenzūra ..., p. 264. 
recorded by Emmanuel de Las Cases when he was on St Helena (Le Mémoire de Sainte-Hélène), and lent it to his acquaintances. ${ }^{15}$ It is actually difficult to determine just how widely books associated with the name of Napoleon, the mere mention of which also implied distinct memories about the changes in the country in 1812 , spread around the country via conspiratorial means. One thing is clear: the censorship applied by the Russian administration performed a certain negative role in supressing the spread of part of the Lithuanian population's 'own' historical memory of 1812 .

It should not be forgotten, however, that representatives of the Great Emigration (Wielka Emigracja), now scattered around Europe, could print works that could reach the Kingdom of Poland illegally, and from there the population of the western provinces of the Russian Empire. The likelihood of this was quite realistic, as an imperial decree of 1833 ordered that those returning to Russia with revolutionary books and publications published in France after the uprising of 1830-1831 would have them confiscated or censored. Thus, Mickiewicz's Pan Tadeusz, czyli ostatni zajazd na Litwie. Historia szlachecka z roku 1811 i 1812 we dwunastu ksieggach wierszem [Master Thaddeus, or the Last Foray in Lithuania: A Nobility's Tale of the Years 1811-1812, in Twelve Books of Verse], which was one of the poet's most famous works, published in Polish in Paris in 1834, could reach readers via illegal means, and remind them of the glorious not-so-distant past illustrated in the events mentioned in his poem. For example, the historic excursus about Napoleon's meeting with Lithuanian volunteers who had arrived to offer their help would have surely appealed to the imaginations, emotions and minds of readers and listeners. At the end of the work, they enthusiastically shout: 'The Greatest One is with us, and we are with Bonaparte!' As is known, the poet was a fan of Napoleon in his youth, and signed his name Adam Napoleon. ${ }^{16}$

The 1830-1831 uprising served to further propel the continuity of the historical memory, where there were participants in the

${ }^{15}$ T. Bairašauskaitè, Mykolas Juozapas Römeris (1778-1853): bajoro viešoji ir privati erdvès XIX a. pirmojoje pusejje (Vilnius, 2011), p. 316.

${ }^{16}$ A. Kalèda, Mitų ir poezijos žemè: Lietuva lenkų literatūroje (Vilnius, 2011), pp. 94$95,98$. 
1812 war among the rebel leaders and ordinary fighters. Glorious examples from the previous war were not used on a broad scale in the rebels' agitational struggle against the 'Muscovites'. But one of the rebels' proclamations did declare that the 'patriotic feelings and heroic militancy' of Lithuanians, renowned over the ages for seeking freedom and independence, were demonstrated along with those of Tadeusz Kościuszko and the Polish general Józef Poniatowski, the leader of the Grande Armée's Fifth Corps, and that they had also 'written an excellent page in history in 1812 and $1813 \cdot{ }^{\prime 7}$ On the other hand, the fact that some of the rebels wore French army uniforms was also a reminder of $1812 .^{18}$

The continuity of the historical memory of 1812 can be associated with the peasants' desire for personal freedom and their opposition to Russia's tyrannical authority. Proclamations made by the Lithuanian rebel leaders in 1831 promised to grant the peasants the same freedoms as those in the Kingdom of Poland, which they happened to have received thanks to Napoleon, even though the French emperor was not named in these declarations. ${ }^{19}$ A book entitled Ponas teisejjaitis arba pasakojimas apie Lietuva ir Žemaitija (The Judge, or a Story about Lithuania and Samogitia) was published in France in 1839 in a print run of several hundred copies. The writer, Jonas Goštautas, who was also one of the leaders of the Lithuanian rebel gangs, created the character of a peasant who volunteered for the Lithuanian army in 1812, participated in all the campaigns in Europe, was awarded the Cross of the Legion of Honour, served and reached the rank of non-commissioned officer in the army of the Kingdom of Poland, and who, on returning to Samogitia, his homeland, was ordered by his master back into serfdom. ${ }^{20}$

${ }^{17}$ Lietuvos TSR šaltiniai, Vol. 1 (Vilnius, 1955), p. 420.

${ }^{18}$ V. Pugačiauskas, XIX a. Lietuvos kariniu daliniu istorija (Vilnius, 2019), p. $5^{8 .}$

${ }^{19} \mathrm{~F}$. Sliesoriūnas, J. Kruopas, 'Nežinomas $1831 \mathrm{~m}$. Lietuvos sukilèlių atsišaukimas Lietuvių kalba', in: Lietuvos TSR Mokslu akademijos darbai, serija A, Vol. 1 (18), (1965), pp. 239-243; F. Sliesoriūnas, 'Klasiniai prieštaravimai 1830-1831 metų sukilime', in: ibid., p. 93 .

${ }^{20} \mathrm{~J}$. Goštautas, Ponas teisëjaitis arba pasakojimas apie Lietuva ir Žemaitija, ed. K. Korsakas (Vilnius, 1967), p. 76. 
Apart from the censorship of written material, the Russian government also applied other measures that aimed to form a Russian version of the historical memory of the 1812 war. This is evident from the monument erected in Kaunas' Town Hall Square in 1843 (the silhouette consisted of an obelisk and an Orthodox cross, reaching a height of 16.35 metres) to mark the $25^{\text {th }}$ anniversary of Russia's victory in the 1812 war. Monuments were erected all over Russia at the sites of the most important battles on the occasion of this anniversary, but as is known, the opponents did not fight in Kaunas. This says quite a lot about the government's official efforts to memorialise its version of history in the country, as its image amid the backdrop of the confluence of the two rivers was used on the coats of arms approved by the emperor for Kaunas and the newly established province. Only 31 veterans who had fought in Russian units in 1812 could be tracked down for the unveiling ceremony. The commemoration of the victory against Napoleon appeared alongside other important celebrations, such as the emperor's birthday, his coronation day, and the name day of the heir to the throne. As the historian R. Civinskas accurately noted, commemoration of the victory against Napoleon was a demonstration of the state's power. ${ }^{21}$ Without a doubt, the whole celebration served political interests, in an effort to remind the urban population of Russia's military achievements by organising yearly military parades in Town Hall Square by the obelisk.

The Emperor Alexander II relaxed policies affecting the population in the western peripheries in the mid-19th century, which influenced the cultivation of the historical memory, such as the amnesty for political prisoners, including participants in the 1830-1831 uprising, the lifting of martial law in the western provinces, a more lenient position towards the Catholic Church, and a more lively cultural life. ${ }^{22}$ Publications aimed at the public at

${ }^{21}$ R. Civinskas , 'XIX a. Vidurio kauniškoji biurokratija', in: Darbai ir dienos, Vol. 4 (13), (1997), pp. 45-46; 'Imperatoriaus pasididžiavimas - į metalo laužą', in: https://kauno.diena.lt/naujienos/kaunas/miesto-pulsas/imperatoriaus-pasididziavimas-i-metalo-lauza-327624 (accessed 2021 o6 7).

${ }^{22}$ Lietuvos istorija, Vol. VIII, Part I: T. Bairašauskaitė, Z. Medišauskienė, R. Miknys, Devynioliktas amžius: visuomenè ir valdžia (Vilnius, 2011), pp. 213-214. 
large mentioned the events of 1812 in Lithuania. The censors tried to control this process; for example, the Vilnius Archaeological Commission's vice-president Michał Baliński wanted to print an account of the visits by Napoleon and Alexander I to Vilnius in 1812, but only managed to have the section about the Russian emperor published. ${ }^{23}$ At the same time, Lithuanian society had probably its first chance to learn more in the official press in Vilnius about the main facts about Napoleon's time in the country, from the guidebook published in Polish and Russian by the publicist, publisher and historian Adam Honory Kirkor. It gave a brief account of the circumstances of Napoleon's stay in the city, and his orders, even mentioning the establishment of the local government, without using the word Lithuania; however, the names and surnames of local nobles who were involved were listed, and its activities were described. ${ }^{24}$ Thus, thanks to this publication, readers had their first, official opportunity to familiarise themselves with historical facts about the realities of 1812 that had not hitherto appeared in the press. Also, the informative publication reached readers from a wider range of social classes. Just as important is the fact that a new generation of people could receive information that did not just come from witnesses to the events.

An additional impulse to the historical memory of the 1812 war was the interest in Napoleon among a certain part of society. The Vilnius Museum of Antiquities, founded at the initiative of Count Eustachy Tyszkiewicz, featured relics from the 1812 war $\left(5^{8}\right.$ in total), alongside exhibits from distant history. They included objects from the time Napoleon spent in Lithuania: part of the weapon collection of Napoleon's adjutant Count Józef Antoni Kossakowski, and C. Kaminskaitė-Nezabitauskienė donated of a lock of hair from the mane of the horse on which Napoleon rode into Vilnius. ${ }^{25}$

${ }^{23} \mathrm{~V}$ pamiat prebyvaniia gosudaria imperatora Aleksandra II v Vilnie, 6 i 7 sentiabria 1858 goda (Vilno, 1858); R. Narunec, Michat Baliński jako mecenas polskolitewskich więzi kulturowych (Warszawa, 1995).

${ }^{24}$ A.H. Kirkor, Przechadzki po Wilnie i jego okolicach (Wilno, 188o), pp. 48-53.

${ }^{25}$ R. Griškaite, 'Vilniaus laikinosios archeologijos komisijos „,neakivaizdininkès“: „gender aspektas“ Vilniaus senienų muziejaus istorijoje (1856-1865)', in: Kova dèl 
Neither should the so-called legend of Napoleon (the French emperor as a symbol of the Polish struggle for freedom), so deeply entrenched in Polish culture and national self-awareness, and popularised in Polish romantic poetry (by Adam Mickiewicz and Juliusz Słowacki), be overlooked. Conversely, in Lithuania we can only really talk about an episodic phenomenon associated with the name of Napoleon and the French. It was firmly believed during the 1863-1864 uprising in Lithuania that France under Napoleon III was a country which would help to liberate it from Russia's yoke and serfdom; however, the 1812 war and Napoleon Bonaparte were hardly used as historical examples inspiring society to fight against Russia. ${ }^{26}$

The communicative memory plays an important role in the historical memory process, as Russian bureaucrats and censors could neither control nor ban it. The creators of the communicative memory were participants in and/or witnesses to military activity in 1812, who shared their experience of the past with their inner circle, through memoirs, stories and war songs. The anonymous author of a memoir described the indelible impression she experienced in her childhood when her grandfather's brother, a participant in the wars in Europe between 1812 and 1814, stared at a picture of Napoleon he had bought, and told them magical things about the Grand Emperor and the fine Frenchmen, saying that there were similar grandfathers with similar recollections in every district of Lithuania. ${ }^{27}$ Even after 45 years had passed since the war, a veteran in a town Čiobiškis continued to wear a medal on a string around his neck that he had received from the Polish General Vincenty Krasinski in $1814 .{ }^{28}$ There could have been at least a thousand such veterans who fought in 1812 and had been in Europe and returned, while the total number who served in

Istorijos: Vilniaus senienu muziejus (1855-1915): mokslo straipsnių rinkinys, eds. R. Griškaitè, Ž. Būčys (Vilnius, 2015), pp. 312, 336-337.

${ }^{26}$ D. Fajnhauz, 1863 Litwa i Biatoruś, Warszawa, 1999, pp. 186-188; A. Zahorski, $Z$ dziejów legendy napoleońskiej w Polsce (Warszawa, 1971), pp. 74-76, 79-81, 9 o.

${ }^{27}$ Różne Wiadomości (Nadesłane). Z listu zacnej Litwinki, Ojczyzna: dziennik polityczny, literacki i naukowy, No 38 (1864).

${ }^{28}$ Konstantinas Tiškevičius, Neris ir jos krantai: hidrografiniu, istoriniu, archeologiniu ir etnografiniu požiūriu, ed. R. Griškaitè (Vilnius, 2013), p. 245. 
exclusively Lithuanian units reached over $17,000 .{ }^{29}$ On the other hand, we should bear in mind that there were also Lithuanian recruits who served in the Russian army and fought against the Grande Armée. It was precisely these participants in the war who were among the main groups spreading the historical memory and who ensured its longevity over several generations.

The realities of the Napoleonic Wars were reflected in war songs in which the various experiences of soldiers were lauded. In one, a peasant from Užnemunè region, which was part of Prussia, was conscripted into the Prussian army, and was glad that the 'king of the French' had arrived thanks to God's will and liberated him from serving the 'prūsokai' (Prussians). This example of conscription is also testimony to how young men then joined the Lithuanian regular army, which was being formed. Enthusiasm for the Grande Armée's victories in Russia and support for the French is reflected in the lyrics of a song: 'We shall storm the Muscovites,' and 'We shall drive out the Muscovites, and make the Polish land clean again'. Another song refers to an episode from the start of the war testifying to the size of the Grande Armée: 'The Frenchman is proud, he drove many kings upon the Russians,' and another episode of a Lithuanian recruit serving in the Russian army singing about an unsuccessful battle against the Grande Armée, 'Even though all of us might stand and fight, the Russian won't be overcome' (... nors visi mes eisim, ruso neparveiksim). There is also a record of Lithuanian soldiers returning after the war from France via Prussia '... back to that grey Muscovy'. ${ }^{\circ}$ Some songs testify to the service by Lithuanian soldiers in the Russian army, and their participation in the battles against Napoleon's army: '... stood in rank and line with the Muscovites, and started to fight the French' (... su maskoliais i glita sustojo, su prancūzais vajavot pradejo)..31

${ }^{29}$ L. Glemža, 'Lietuviški kariniai daliniai Prancūzijos kariuomenėje 1812-1814 m.', in: Karo archyvas, Vol. XVIII (2003), pp. 146-154; D. Nawrot, Litwa i Napoleon w roku 1812 (Katowice, 2008), p. 622.

${ }^{3 \circ}$ M. Biržiška, Dainu atsiminimai iš Lietuvos istorijos (Vilnius, 1920), pp. 59-6o; B. Dundulis, Lietuva Napoleono, pp. 118-119; J. Basanavičius, Rinktiniai raštai (Vilnius, 1970), pp. 440-442, 446-447, 470; A. Juška, Lietuviškos dainos, Vol. 1 (Vilnius, 1954), p. 401.

${ }^{31}$ D. Krikštopaitytè, Lietuviu liaudies karinès-istorinès dainos (Vilnius, 1965), p. 167. 
Thus, war songs reflect the individual experiences of soldiers under the conditions of war, as well as the course of the main events and an assessment of the war. Due to being spread verbally, these songs could be passed on to the next generation, and became a fundamental historical memory source regarding the 1812 war, bearing in mind the fact that they were only written down in the second half of the 19th and the early 20 th century. Stories about 'French graves', 'French hills', 'French roads' and treasure buried by the French, sunken in various locations, like ponds and lakes, played a similar role, also being passed on from one generation to the next. In stories about 'French hills', the French were said to build hills or mounds for convenience, and could do so rather quickly because of the large number of soldiers. There are only a few such stories, mostly from particular areas that the main forces of the Grande Armée marched through, for example, where it crossed the River Nemunas (Piliuona or the famous 'Napoleon's Hill' not far from Prienai). ${ }^{32}$ There are numerous place names in Lithuania associated somehow with Napoleon and the French (but not necessarily directly related to them). One crooked oak tree in the village of Upytès Tarnagala in the Panevėžys district has been named Napoleon's staff; near Krekenava, there is a bridge named after Napoleon; and old-timers from the village of Raginènai would say that the French had buried seven barrels of gold in a pine grove; while Drulupis cemetery is also known as 'the French hill'. ${ }^{33}$

The collective memory of the war is reflected in the above place names. These narratives travelled uninhibited from one generation to the next, as relics of that time, with many coming from all over the former territory of the GDL, from Užnemunė to the Vitebsk and Mogilev provinces. As the Belarusian researcher U. Lobač states, the memorisation mechanism of historic events forms the traditional world-view of a village community, to which

${ }^{32}$ B. Kerbelytè, Lietuviu liaudies padavimai (Vilnius, 1970), pp. 119, 121; J. Ambrozaitis 'Prancūzkapiai', in: Karys, No 33 (1930).

${ }^{33}$ D. Aidukaitė, 'Didžiojo prancūzų karvedžio atgarsiai Pietų Lietuvoje', in: http:// gintarinesvajone.lt/2013/o5/13/didziojo-prancuzu-karvedzio-atgarsiai-pietu-lietuvoje/ (accessed 2021 o9 28); P. Juknevičius, 'Napoleonas Panevėžio kašte, Iš mūsų krašto praeities', in: Tërynè, No 13 (6387), (2006). 
precedents, turning-points, critical and extraordinary events are fundamental and significant; war is undoubtedly one such event. Something as unforgettable as war shifts from the relevant history, which consists of personal recollections rich in details, into the folkloric (epic) realm of history. ${ }^{34}$

The likelihood of reviving and upholding their 'own' historical memory in the second half of the 19th century, when contemporaries of the war had already died, was minimal. The Imperial Russian government held a monopoly over the indoctrination of young people's world-view, especially after the uprising of 1863-1864, and sought to instil the 1812 war as an example of the empire's might, the glory of the Russian nation and its heroic struggle. In history textbooks, the 1812 war was treated as a war fought not just by the Russian Empire, but by the whole Russian nation (all social groups), in which the people played one of the most important roles:

At this critical time, the Russian nation showed its patriotic spirit. It heroically endured all the toils of war associated with the enemy's invasion, and was prepared for sacrifices in the name of the liberation of the Fatherland [Otechestvo]. The nobility funded weapons for troops of soldiers, while those soldiers, peasants, sacrificed themselves to defend the Fatherland. ${ }^{35}$

This was the assessment conveyed in the textbook written by Dmitri Ilovaiskii, which was the main source of teaching material for history in state gymnasiums across the Northwest Region in the second half of the 19th century. In his textbook, Ilovaiskii mentioned that Napoleon had the intention of restoring 'the former statehood of the Poles', and created a separate administrative unit, the Duchy of Warsaw, which is why the 'duchy's Poles' so willingly joined the ranks of the French emperor's army. ${ }^{36}$ However, the author did not elaborate on society's attitudes towards Napoleon in the lands of the former GDL. This discourse appeared in a history

${ }^{34}$ U. Lobačius, 'Archeologiniai paminklai tradiciniame liaudies pasaulèvaizdyje (Baltarusijos-Rusijos paribys)', in: Liaudies kultūra, No 5 (2015), pp. 49-5o.

${ }^{35}$ D. Ilovaiskii, Kratkie ocherki russkoi istorii. Kurs starshego vozrasta. 9-oie izdanie (Moskva, 1868), p. 366.

${ }^{36}$ Ibid. 
reader used in the Northwest Region written by the local author Aresnii Turtsevich, a teacher at the Vilnius First Gymnasium. It was rated very poorly by the local Poles, who considered it to be 'hurting their religious and national feelings'. ${ }^{37}$ In his reader, Turtsevich stressed that by supporting Napoleon, the Poles, or more precisely, the nobility, did not appreciate the efforts made by Emperor Alexander I to develop Polish culture and science; even after the 1812 war, the Poles were not satisfied with the relatively autonomous legal status granted to the Kingdom of Poland, and they fostered 'predatory aims, to bring Lithuania, Belarus, Podole and Volhynia under their control' $3^{3}$ According to Turtsevich, the Poles inspired the 1830-1831 uprising, after which 'they received just what they deserved for not appreciating the earlier efforts made by Alexander I for their benefit.'39 Thus, Turtsevich used the 1812 war as another argument to justify the government's discriminatory policy against 'people of Polish origin', which incidentally was even more prevalent after the 1863-1864 uprising. Regardless of requests made by Polish parents to the Board of the Vilnius Education District, Turtsevich's history reader for the Northwest Region was the main history textbook in secondary schools even after the events of 1905, when changes began to unfold in government education, and partly in national policy as well, in the Russian Empire.

The Russian government tried to exploit the 1ooth anniversary of the 1812 war, held amid the reverberations of the events of 1905 , as yet another opportunity to consolidate society in the empire, and, based on specific historical examples, to demonstrate unity between the government and society, and to elevate the

${ }^{37}$ At the end of 1906, Polish schoolchildren's parents appealed to Boris von Wol'f, the supervisor of the Vilnius Education District, asking him to remove Turtsevich's history textbooks from the teaching process, because 'the religious and national feelings of Polish pupils were being hurt.' Secret note from the supervisor of the Vilnius Education District B. Wol'f to the minister of education A. Schwartz (19 March 1908), Lithuanian State Historical Archives (LVIA), col., 567, inv. 26, file 80oa, p. 18.

${ }^{38}$ Chrestomatia po istorii Zapadnoi Rosii. Uchebnoe posobie dlia uchenikov starshikh klassov srednikh uchebnykh zavednii, sost. A. Turtsevich, Vilenskoi pervoi gimnazii i Vilenskoi rimsk.-kat. duchovnoi seminarii (Vil `na, 1892), p. 743.

${ }^{39}$ Ibid., p. 746. 
authority of the Romanov dynasty in different social groups. ${ }^{4^{\circ}}$ The commemoration was coordinated by a pre-organised intelligence commission, which aimed to create a common memory culture across the whole Russian Empire for the 1812 war. ${ }^{41}$ However, in the Northwest Region, the local government structures, primarily the Vilnius War Council and the Board of the Vilnius Education District, planned to create a so-called regional narrative about the events of the 1812 war. At the time, some of the Russian intelligentsia, mainly teachers, who were the most active participants in the creation and spread of the propaganda discourse in the Northwest Region, openly admitted that, regardless of the government's efforts to supress the historical memory and the indoctrination of the local Poles, the latter had managed to uphold and foster the idea of the 1812 war as an assessment of the Polish nation's freedom and its fight against the Russian government. ${ }^{42}$ Thus, in Russian academic and popular historical literature that was specially written to commemorate the 1ooth anniversary of the 1812 war, the aim was to show the invalidity of the Poles' hopes being linked to Napoleon, stressing that only one part of local society took part in the struggle to see lost statehood restored in the Northwest Region, the nobility, which represented only the Poles, and not the Lithuanians or the Belarusians. An excellent example of this so-called regional narrative is the publication of historical documents compiled and released in 1912 by Yuri Tatishchev, the governor's special orders official, who actively participated in government-organised public memorial events to mark the 1812 war. $^{43}$

${ }^{40}$ Cf. see: T. Saburova, 'The Patriotic War of 1812 in the Commemorative Practices ..., p. 245 .

${ }^{41}$ Memorial events across the whole Russian Empire (memorial celebrations, free public performances, readings) had to be organised according to the same, general pre-approved programmes.

${ }^{42} \mathrm{Cf}$. Fedot Kudrinskii, a Russian language and literature teacher in schools in Vilnius, who published several historical publications devoted to the events of the 1812 war in Vilnius, openly wrote: 'Regardless of Napoleon's failures in Lithuania, his name has been passed on to younger generations of Poles as a symbol of greatness.' F. Kudrinskii, Otechestvennaia voina 1812 goda (s 10 risunkamiv tekste) (Vilna, 1912), p. 22.

${ }^{43}$ Akty i dokumenty arkhiva Vilenskogo, Kovenskogo i Grodnenskogo generalgubernatorskogo upravleniia, otnosiashchiesia k istorii 1812-1813 gg. Chast pervaia. Perepiska po voennoi chasti (Vilna, 1913). 
In this publication, Tatishchev emphasised that, unlike the Russian Emperor Alexander I, Napoleon manipulated the Poles' mood and goals. Tatishchev stressed that Napoleon had no serious intention of ever restoring the 'political independence of the Poles' in the lands of the former GDL; he was merely exploiting the spiritual exaltation of Poles and fed them various promises. 'Napoleon very cleverly kept the Poles in a state of nervous anxiety, always tempting them with the ghost of independence ${ }^{44}$ is how Tatishchev summarised Napoleon's stance regarding the Poles. Unlike some Russian historians, who accentuated the inconsistencies and duality of the policies of the Emperor Alexander I directed at the Poles in their academic work, ${ }^{45}$ Tatishchev pointedly stated that the Russian emperor had even considered restoring the 'Polish-Lithuanian state within its historical borders.' ${ }^{46}$ However, the unacceptable behaviour of the Poles during the 1812 war and their support for Napoleon had halted the realisation of these plans conceived by Alexander I.

In the historical publication mentioned above, Tatishchev stressed that only one sector of local society had shown amiability towards Napoleon, namely the nobility, who in turn represented almost exclusively Poles. The other sector of society, the common

${ }^{44}$ Ibid, p. 4.

${ }^{45}$ For example, a publication containing source material prepared by Konstantin Voenskii in 1909 stressed that the policies of Alexander I in the Northwest Region were characterised by 'constant fluctuations, wavering and uncertain goals' (Predislovie, Akty, dokumenty i materialy dlia politicheskoi i bytovoi istorii 1812 goda, sobrannyie i izdannyie po porucheniu ego imperatorskogo velichestva velikogo kniazia Mikhaila Aleksandrovicha, pod redaktsiei K. Voenskogo. Tom pervyi, (S-Peterburg, 1909), p. VII). Aleksandr Pogodin also recommended a more cautious assessment of the policies of Alexander I in the Northwest Region. According to Pogodin, 'On one hand, the tsar encouraged the development of the Lithuanian and Belarusian provinces, supported Polish education and protected the Polish administrative model in the provinces. On the other hand, under the influence of Russian nationalists, he constantly violated this order with separate decrees. The scale on which Emperor Alexander I fluctuated was indeed great, shifting from the idea of restoring the Grand Duchy of Lithuania by joining it to Poland, to seeking the total Russification of the land.' [A. Pogodin], 'Napoleon i Litva,', Otechestvennaia voina i russkoe obshchestvo, 1812-1912, Vol. III (Moskva, 1911), p. 163.

${ }^{46}$ Akty $i$ dokumenty arkhiva Vilenskogo, Kovenskogo i Grodnenskogo generalgubernatorskogo upravleniia, otnosiashchiesia k istorii 1812-1813 gg. Chast vtoraia. Perepiska po chastigrazdanskogo upravleniia (Vilna, 1912), p. 118. 
folk, which Tatishchev identified as the Lithuanian and Belarusian nations, sought 'peace and quiet'. ${ }^{47}$ The Lithuanians' and Belarusians' 'clear thinking implied that they were better off siding with the Russian nation, as otherwise national extinction and political death awaited'. ${ }^{48}$ This accentuation that Tatishchev expressed was not incidental. First of all, he had already been witness to the ever-growing national issues of the Lithuanians and Belarusians, the ever-more evident antipathy between Poles and Lithuanians, and in part, the Polish and Belarusian national movements, and sought to exploit them. By stressing that during the 1812 war, the infusion of the ideas and goals of political independence at all layers of local society was arguable, it was as if Tatishchev sought to 'stop in their tracks' any future projections of the lands of the former GDL connected to the Kingdom of Poland as a common state unit, which the Polish political elite was already publicly announcing at the time. Tatishchev recommended that the leaders of the Lithuanian and Belarusian national movements project their political futures as components of the Russian Empire, especially since both Tatishchev and Sergei Tomilin, the co-author of his publications and a member of the Vilnius Society for the Memory of the Patriotic War (Vilenskii kruzhok revnitelei pamiati Otechestvennoi voiny 1812 goda), supported the concept of the GDL as a part of the 'national territory' of Russia. This is why the publication of sources mentioned stressed that the partitions of the Polish-Lithuanian Commonwealth, the events of the 1812 war, and the uprisings in 1830-1831 and 1863-1864 showed how 'painfully the connection process progressed of the once-separated part of Rus'ia with the all-Russian Great Fatherland'. ${ }^{49}$ In Tomilin's map ' 1812 War Activity from the Nemunas to Moscow', which came out in two editions, the marking of the borders of the former GDL lands coincided with the marking of the 'state Russian lands' (gosudarstvenaia russkaia granitsa), implying the

${ }^{47}$ Ibid.

${ }^{48}$ Ibid.

${ }^{49}$ Akty i dokumenty arkhiva Vilenskogo, Kovenskogo i Grodnenskogo generalgubernatorskogo upravleniia, otnosiashchiesia k istorii 1812-1813 gg. Chast pervaia, p. I. 
conclusion that Napoleon's army invaded the 'national territory' of Russians, as opposed to the domains of the Russian Empire..$^{\circ}$ This map, which may be viewed as a separate semiotic work with its own assessment of the 1812 war, was used in the education process, and in this way the so-called regional narrative about the 1812 war was 'transferred' from works by academic historians to history teaching material, being used in public speeches made by history teachers at school events commemorating the 1812 war, $^{51}$ and as an emotional impact and visual propaganda measure..$^{52}$ Yet the question remains open as to why the government-administered assessment of the $\mathbf{1 8 1 2}$ war settled so well in the minds of schoolchildren, what cultural and political position it could have prompted, and how capable it was in competing against other assessments of the 1812 war that were kept alive and often fostered within families. Also, in certain cases, the government's efforts to promote 'its own' interpretation of the 1812 war experienced unexpected failure, as happened with the Vilnius Society for the Memory of the Patriotic War.

This society was founded in 1910 by the Vilnius War Council, in the hope that it would help promote an interpretation of the 1812 war that was acceptable to the government, as had been the

${ }^{50}$ Karta voiny 1812 goda ot Nemana do Moskvy, sost. S. Tomilin (Vilna, 1912).

${ }^{51}$ 'Istoria Otechestvennoi voiny 1812 goda. Rech' prepodavatelia istorii Vilenskogo realnogo uchilishcha I. I. Iashchinskogo, proiznesionnaia na torzestvennom akte, posviashchionnom chevstvovaniui 10o-letnego iubileia Otechestvennoi voiny, sostoiavshegosia v uchilishche 27 avgusta 1912 goda', LVIA, col. 567, inv. 1, file 1995, p. 8; Prazdnovanie iubileia Borodinskoi bitvy v Ponevezhskoi uchitelskoi seminarii, LVIA, col. 567, inv. 1, file 1999, p. 126; Iubileinaia rech` 26 avgusta 1912 goda v Svichloskoi uchitelskoi seminarii, p. 22; O narodnom kharaktere Otechestvennoi voiny. Rech', proiznesionnaia na torzhestvennom iubileinom akte v pamiat` stoletia Otechestvennoi voiny prepodavatelem Bobruiskoi muzhskoi gimnazii I. M. Shelepinym, p. 138; Iubileinaia rech`, sostavlennaia i proiznesionnaia prepodavatelem Mogilevskoi muzhskoi gimnazii Antonom Luchinym, 26 avgusta 1912 goda, p. 168.

${ }^{52}$ For example, when organising historical storytelling with projected images at state secondary schools, the photography album of Sergei Prokudin-Gorski would be shown (War Sites from 1812), where the events of the 1812 war were symbolised by the Church of St Aleksandr Nevsky in Vilnius on George Square which was constructed to condemn the rebels of the 1863-1864 uprising and to clearly identify the victors. Cf. see: Prazdnovanie 10o-letnego iubelieia Otechestvennoi voiny $v$ Vilenskom uchebnom okruge, sost. A.P. Belkovskii (Vilna 1913), p. 5 . 
case in Warsaw, Kiev and Odessa. ${ }^{53}$ However, despite the expectations of local officials, the society founded in Vilnius attracted few members, and devoted more attention to scientific historical research into the 1812 war than to propaganda activities. ${ }^{54}$ The society's president, Nikolai Bernatskii, a war judge in the Vilnius Military District Court, who prepared separate historical publications about military activity in Vilnius and its surroundings, ${ }^{55}$ suggested that not only should Russian military commanders be memorialised in Vilnius (e.g. to rename streets in Vilnius after the Russian General Mikhail Kutuzov, and to erect a monument in Vingis Park [then known as Zarechie Park], in Vilnius which the Russian emperor had visited during the war), but also the French soldiers. At first, Bernatskii's suggestion and the initial steps taken towards its realisation appeared unacceptable to local officials, and even dangerous.

By the beginning of the 2oth century, the nature of interstate relations between France and the Imperial Russian government had changed. Official documents from this time abandoned the formula that in 1812 the Russian Empire fought in and won a war against France, and instead the abstract term 'dvadesiat iazykov' [20 nations] started being used. This implied that Russia fought an army of various nationalities (not just French). ${ }^{56}$ Representatives

${ }^{53}$ Branches of the Imperial Russian War History Society (Imperatorskoe russkoe voenno-istoricheskoe obshchestvo) operated in these cities. The society's branch in Warsaw foresaw the founding of a historic war museum to memorialise the events of the 1812 war, organised excursions for teachers and pupils to battle sites, prepared popular publications about the war in the Kingdom of Poland, and organised free war memorialisation events in Warsaw. In the future, there were also plans to grant the Vilnius Society for the Memory of the Patriotic War the same status as this war history society. Cf. see: V. Pavlenko, O podgotovke prazdnovaniia 10o-letnego iubilieia voiny 1812 goda v Vilenskoi i Varshavskoi guberniakh, in: Arkheiograficheskii ezhegodnik za 2012 god (Moskva, 2016), pp. 149-152.

${ }^{54}$ The members of this society collected documents, art and oal accounts about the presence of Napoleon's army in the Northwest Region, and monuments (shrines, crosses) marking burials of Russian and French soldiers, and planned to publish a separate collection of historical sources and maps about the war within the territory of the Vilnius War Council.

${ }^{55}$ N. Bernatskii, Sobytiia v Vil'ne vo vremia Otechestvennoi voiny. Izdanie Vilenskogo kruzhka revnitelei pamiati stariny 12 goda (Vil’na, 1912).

${ }^{56} \mathrm{E}$. Bochkov, 'V interesakh podderzhaniia nashikh serdechnykh otnoshenii s Frantsiei. Uchastie frantsuzskikh delegatsii v merompriatiakh, posviashchionnykh 
of France were invited to and were expected to participate in one of the most important joint state events marking the 1ooth anniversary of the 1812 war, held at the site of the Battle of Borodino (26 August [7 September] 1812).57 Thus, Bernatskii's relations with the French Embassy in St Petersburg did not at first appear out of place. His suggestion to erect a monument honouring French soldiers in Vilnius coincided with the earlier ideas proposed by a joint commitee representing the French minister of war and foreign affairs, descendants of French military leaders, and French artists. They foresaw monuments being built for French soldiers in Smolensk and on the site of the Battle of Borodino. ${ }^{8}$ The attaché from the French Embassy, Colonel Matton, arrived in Vilnius on 2 March 1912, and together with Bernatskii and the Vilnius city major, coordinated a location for the monument honouring French soldiers. ${ }^{59}$ However, opinions about the site of the monument did differ. Matton suggested erecting a monument in the square in front of St Catherine's Church, where French soldiers kept documents and medicines in 1812. Meanwhile, the Vilnius myor, a position then held by the active Polish political and public figure Michał Węsławski, planned to allocate a plot of land free of charge in front of the Vilnius city theatre, the former Vilnius Town Hall. The choice of this site was Government also quite deliberate: it was where the Lithuanan Provisional, formed on Napoleon's orders, convened on 1 July 1812. A military parade was held in Town Hall Square to mark Napoleon's name day, and a celebration was organised for the city's inhabitants. Thus, this particular site for the monument honouring French soldiers would have brought back memories for the local Poles about the hope of restoring their former statehood, it being associated with Napoleon. The symbolic meaning of the future monument was understood perfectly well

stoletiiu Borodinskogo srazheniia', in: Peterburgskii istoricheskii zhurnal, No 2 (2017), p. 239.

${ }^{57} \mathrm{Cf}$. see: G. Ulianova. 'Iubilei Borodinskoi bitvy i problema transformatsii istoricheskoi pamiati: istoriografia i periodizatsiia', Epokha 1812 goda v sudbakh Rosii i Evropy, Materialy mezdunarodnoi nauchnoi konferentsii (Moskva, 8-11 oktiabria 2012 g.), sost. G.N. Bibikov, L.V. Mel'nikova (Moskva, 2013), pp. 498-509.

${ }^{5} \mathrm{Cf}$. see: E. Bochkov, Vinteresakh podderzhaniia ..., pp. 240-241.

${ }^{59}$ 'Frantsuzskii pamiatnik v Vil'ne', Vilenskii vestnik, 2 marta, No 2612 (1912), p. 3. 
by part of the local Russian intelligentsia, who started to criticise actively the monument idea conceived by the Vilnius Society for the Memory of the Patriotic War in the periodical press. ${ }^{6 \circ}$ It is difficult to determine exactly why the monument memorialising French soldiers in Vilnius was never realised. We can only point out that the transport of the monument to French soldiers from Paris to the battlefield at Borodino was interrupted in 1912. ${ }^{61}$ Also, the monument in Smolensk honouring the memory of French soldiers did not end up being erected.

However, the active support for the initiatives for a monument in honour of French soldiers shown by the local Polish community showed that it had managed to maintain 'its own' historical memory of the 1812 war for a hundred years, associated with the hope of restoring the Polish-Lithuanian Commonwealth, and seeing the 1812 war as a symbol of the Polish struggle for freedom and political independence. 'The memory about Napoleon in our Nation is part of our national soul, it is a sacred tradition of our glorious past, an ideal, our guiding star, which has shone through the century and strengthened our Nation, ${ }^{62}$ is a comment on the importance to the Polish nation of the events of the 1812 war made by the Polish National Democrat Party member Jan Obst. To commemorate the 1ooth anniversary of the war, Obst printed an extensive article in the culture and science magazine Litwa $i$ Ruś edited in Vilnius, published historical sources on the activities of the Lithuanian Provisional Government, presented portraits of the members, and had a medal created to commemorate the anniversary. ${ }^{63}$ Before

\footnotetext{
${ }^{60}$ The most intense discussion took place in the Russian periodical publication Vilenskii voennyi listok. Cf. see: 'Prebyvanie frantsuzkogo voennogo agenta v Vil'ne', Vilenskii voennyi listok, 2 maja, No 626 (1912), p. 3; V. 'Fedorenko, O predostavlenii mesta dlia sooruzheniia pamiatnika pogibshim v 1812 godu', Vilenskii voennyi listok, 4 marta, No 614 (1912), p. 4.

${ }^{61}$ The historian Evgenij Bochkov presumes that the sinking of the ship the Kursk in the North Sea which was transporting the monument was the work of Russian government structures. Cf. see: E. Bochkov, Vinteresakh podderzhaniia..., p. 241.

${ }^{62}$ J. Obst. 'Przedmowa. Rok 1812 na Litwie'. Litwa i Ruś. Miesięcznik ilustrowany, poświęcony kulturze, dziejom, krajoznawstwu i ludoznawstwu. Maj-czerwiec, Vol. II, z. II/III, (1912), p. 66.

${ }^{6}$ Litwa i Ruś. Miesięcznik ilustrowany, poświęcony kulturze, dziejom, krajoznawstwu i ludoznawstwu. Maj-czerwiec, Vol. II, z. II/III, 1912.
} 
long, the material prepared by Obst was reprinted as a separate publication by the Polish Teachers Union (Zwiazek nauczycielstwa polskiego), who sought to use it in the illegal teaching process, ${ }^{64}$ and apparently not just in the Kingdom of Poland, but in the lands of the former GDL as well..$^{65}$

In the Polish national discourse at the beginning of the 2oth century, the 1812 war started being used as yet another historical argument (in addition to the 1794, 1830-1831 and 1863-1864 uprisings), encouraging the projection of a common Polish and Lithuanian political future. Obst, the Polish National Democrat already mentioned, based his claims on the historical works of the Warsaw University graduate Janusz Iwaszkiewicz, in which it was claimed that during the 1812 war 'all of Lithuania ${ }^{66}$ was ignited by intense patriotism, surpassing even Polish patriotism,' while the Lithuanian Provisional Government 'sought to unite the Polish nation into one body, an integral union of the Crown and Lithuania within the boundaries of the old Rzeczpospolita. ${ }^{67}$ In

${ }^{64}$ Napoleonowi: 1812-1912 (wojny napoleonowskie a Litwa) (Warszawa [1912]).

${ }^{65}$ Most of the Polish education and culture societies in the lands of the former GDL were under the influence of the National Democrats, while teachers at legal, and later illegal, schools used history textbooks published in Warsaw where, unlike the academic historical literature in which the participation of Poles in the 1812 war started being treated as a political mistake, the image of Napoleon promulgated in romantic poetry was still being upheld. After 1908, when the government closed down the Polish education society Oświata (Education), Polish periodical editorial boards partly took over the process of educating youth by starting up magazines for school and university students. These magazines, such as the youth magazine Pobudka (Stimulus), published in Vilnius, featured reprints of poetry by Mickiewicz and Słowacki, and presented the political provisions of professors at Vilnius University, some of whom were members of the Lithuanian Provisional Governing Commission. Cf. see: L. Życka, Krótki rys dziejów tajnej oświaty polskiej na ziemi Wileńskiej od 188 o do 1919 (Wilno, 1932), p. 13; H. Romer-Ochenkowska, Z dziejów tajnej oświaty w Wilnie i Wileńszczyźnie, Nasza walka o szkotę polska 1901-1917. Opracowania, wspomnienia, dokumenty, ed. B. Nawroczyński, Vol. II (Warszawa, 1934), p. 383; P. Dąbrowski, Narodowa Demokracja bytego Wielkiego Księstwa Litewskiego. Studium z zakresu myśli politycznej i działalności obozu narodowego na ziemiach litewsko-biatoruskich w latach 1897-1918 (Kraków, 2010).

${ }^{66}$ Iwaszkiewicz used the term Lietuva (Litwa) [Lithuania] to describe all the lands of the former Grand Duchy of Lithuania.

${ }^{67} \mathrm{~J}$. Iwaszkiewicz, 'Litwa w przededniu wielkiej wojny 1812 roku', in: Biblioteka warszawska, Vol. 4 (1906), p. 465. 
1918, when the question of statehood became particularly relevant in the Polish and Lithuanian political discourses, Obst repeated his earlier ideas, stressing that

Poland and Lithuania had to unite, as they were bound by a long-lived common history: the unions of Horodło and Lublin [...] the desire for liberty, and the struggle for freedom together with [Tadeusz] Kościuszko, Napoleon, and during the 1831 and 1863 uprisings. ${ }^{68}$

\section{Political and national discourses on the historical memory}

After 1905, the Lithuanian intelligentsia had more opportunities to declare publicly their assessments of historical events compared to previous years. However, in the Lithuanian historical narrative at that time, the events of the 1812 war received very little attention, often being viewed similarly to the interpretation of the 1863-1864 uprising. As Darius Staliūnas has accurately pointed out, the 1863-1864 uprising was seen as a concern of the Poles and the Polonised Lithuanian nobility in the Lithuanian historical discourse, and when combined with the 1830-1831 uprising, 'the Polish uprising. ${ }^{69}$ At the end of the 19th and in the early 2oth centuries, the Lithuanian historical narrative was based on the Lithuanian nationalist ideology, where the most important criterion for nationhood was language, and one of the most important tasks of ethnocultural activities was to distance Lithuanian society from Polishness. Lithuania's history was perceived as the history of the Lithuanians, that is, the people who spoke Lithuanian, which meant that only the early history of the GDL up to the times of Duke Vytautas (1350-1430) or the Union of Lublin (1569) was considered 'their' history, for it was created and overseen by Lithuanians..$^{70}$ The later history of the GDL was seen as part of the Polish heritage, and was subsequently paid little attention in Lithuanian versions of the history of Lithuania. The trends in this particular Lithuanian historical narrative from the late 19th

${ }^{68}$ J.O. [Jan Obst], O naszą przeszłość, Dziennik Wileński, 13 XI (1918), p. 1.

${ }^{69}$ D. Staliūnas, Savas ar svetimas paveldas? 1863-1864 m. sukilimas kaip lietuviu atminties vieta (Vilnius, 2008), pp. 28-29.

${ }^{7 \circ}$ Ibid., p. 28. 
and early 2oth centuries are captured perfectly in the history of Lithuania written by the clergyman and author Jonas Mačiulis (under the pseudonym Maironis).

Maironis' version of the nation's history was not only one of the broadest Lithuanian histories in terms of its scope in the late 19th and early 2oth centuries, but also the most frequently reprinted Lithuanian book of its kind up to the First World War, and primary source material for teaching history. ${ }^{71}$ However, brief mentions of the 1812 war and assessments of the 1830-1831 and 1863-1864 uprisings only appeared in the third edition (1906). Maironis associated the 1812 war and the uprisings with the hope of restoring the former traditions of statehood. He mentioned that 'Napoleon I had aroused everyone's hopes in $1812,{ }^{72}$ though Napoleon's 'promises were not sincere, and he ended up being defeated himself'. ${ }^{73}$ This latter emphasis made by Maironis in his assessment of the events of the 1812 war was not incidental. His writing belonged already to the group of politically orientated works in which a discussion of Lithuania's 19th-century historical experiences was used as a platform for the declaration of political provisions and stances. $^{74}$ That is why, when writing about the outcomes of the 1812 war, Maironis stressed that only the Poles achieved some temporary benefits, but not the Lithuanians. After the Congress of Vienna (1814-1815), the Poles managed to preserve 'at least part of their former homeland, ${ }^{75}$ that is, part of the Duchy of Warsaw formed by the Treaty of Tilsit (1807) was incorporated into the Russian Empire as a separate administrative unit, the Kingdom of Poland. However, after the 1830-1831 uprising, and especially after 1863-1864, the situation of the Poles and the Lithuanians more or less equalised. According to Maironis, ever since then, 'the increasingly impoverished and mournful life of Lithuanians

${ }^{71}$ A. Gieda, 'Maironio istoriko fenomenas', Maironio balsai. Küryba, veikla, atmintis, ed. M. Žvirgždas (Vilnius, 2019), p. 395 .

${ }^{72}$ Maironis (Š.M-lis), Lietuvos istorija su kunigaikščiu paveikslais ir žemlapiu, 3rd ed., 1906 (Petropilis, 19o6), p. 210.

${ }^{73} \mathrm{Ibid}$.

${ }^{74}$ A. Gieda, 'Maironio istoriko fenomenas', p. 39 o.

${ }^{75}$ Lietuvos istorija su kunigaikščiu paveikslais ir žemlapiu, p. 210. 
and Poles commenced, ${ }^{76}$ which was potentially meant to change after the Russian Empire's failed war against Japan (1904-1905). ${ }^{77}$

In the Lithuanian public discourse in the early 2oth century, the 1812 war, much like the events of the $1863^{-1864}$ uprising, ${ }^{78}$ was viewed as if it was a 'history lesson'. In 1905, when Vilniaus žinios, the first Lithuanian daily newspaper in Lithuania, declared that historical texts had to perform a strongly educational function, the context of the events of the 1812 war were used. In his development of a written concept of Lithuania's history through the interaction of the past, present and future, the article's author noted that: 'In Napoleon's times, the Poles were painfully wrong in believing that by spilling their blood for his ideas they would be saving not just their homeland but also their nation. ${ }^{79}$ This assessment of the events of the 1812 war could have implied two conclusions in the minds of readers of this periodical: first of all, to see the 1812 war as a Polish and not a Lithuanian site of historical memory; second, in the light of historical examples, including the events of the 1812 war, the Lithuanian political elite were being recommended to take political action in response to the realities of the day, that is, the might of the Russian Empire.

The assessment of the 1812 war as a site of historical memory that was foreign to Lithuanians also reflected the position of the Lithuanian intelligentsia in 1912 when marking the 1ooth anniversary of these events. Unlike the Polish periodical press, the commemoration of the 1812 war received little attention in the Lithuanian press. For example, the Lithuanian newspaper Viltis announced the official memorial programme for the anniversary of the 1812 Patriotic War in advance, ${ }^{80}$ and several days later it

${ }^{76}$ Ibid.

${ }^{77}$ In the third edition of the history of Lithuania, which was published in 19o6, Maironis, like most of the Lithuanian intelligentsia of the day, hoped that the announcement of the manifesto of the Russian Emperor Nicholas II on 17 (30) October 1905 would bring about significant changes to the Imperial Russian government's national policy.

${ }^{78} \mathrm{Cf}$. see: D. Staliūnas, Savas ar svetimas paveldas? p. 34.

${ }^{79} 21$ April (4 May) No 99 (1905), p. 1.

${ }^{80}$ 'Kronika. Vilniuje. Prancūzų karo jubiliejus', Viltis, 24 August 1912, No 100 (735), p. 2. 
was briefly mentioned that 'many people gathered' to watch the memorial events. ${ }^{81}$ However, a separate or more comprehensive assessment of the 1812 war or its memorial was not given in the Lithuanian newspaper. The 1812 war was called in this publication 'the war of the Russians against the French', ${ }^{82}$ which could easily have generated a foreign, non-Lithuanian site of historical memory assessment of the $\mathbf{1 8 1 2}$ war among Lithuanian readers. It is not so difficult to explain why the Lithuanian newspaper Viltis took this particular stance.

At the time, most of the newspaper's correspondents were Catholic clergy, who held an openly negative view of the events of the 1812 war, both before and after the anniversary, taking into account Napoleon's policies towards the Catholic Church. ${ }^{83}$ In 1914, a long article was published in the St Casimir's Society publication Kauno kalendorius entitled Napoleono nepasisekimas [Napoleon's Failure], which presented an image of the French emperor as a detractor of the Christian religion and an enslaver of nations. ${ }^{84}$ Unlike periodical publications, it was aimed at a very specific group of readers, people of peasant origin. The Vilniaus kalendorius published by the daily newspaper Lietuvos ūkininkas should also be considered this kind of publication, which had relatively large readerships. In 1912, Matas Untulis, a pedagogue and member of the Lithuanian Social Democrat Party, translated into Lithuanian extracts from the historical texts about the events of the 1812 war by the Russian writer Nikolai Rubakin for Vilniaus kalendorius. ${ }^{85}$ In these publications, Napoleon is viewed as a leader possessing a 'great mind, intelligent and clever', who fooled the

\footnotetext{
${ }^{81}$ 'Kronika. Vilniuje. Šimto metų sukaktuvių paminėjimas', Viltis, 1912, No 102 (737), p. 2.

${ }^{82}$ Ibid.

${ }^{{ }^{3}} \mathrm{Cf}$. the magazine $\breve{S}$ altinis, which was sympathetic to the Catholic Church, featured a drawing of Napoleon in 1906 with the caption 'A conquered leader'. Skrebenis [Juozas Valiokaitis], 'Mųsų paveikslai. İveiktas vadas', Šaltinis, 12 December (29 November) No 37 (1906), p. 585 .

${ }^{84}$ R.M. [?], 'Napoleono nepasisekimas', Kauno kalendorius 1915 metams. Šv. Kazimiero draugijos leidinys (Kaunas, 1914), pp. 47-49.

${ }^{85}$ M. Untulio [Matas Untulis], 'Napoleonas', Vilniaus kalendorius 1913 metams (Vilnius, 1912), pp. 63-69.
} 
peasantry by promising to abolish serfdom: 'The darker ones did not even consider the thought that Napoleon was not a do-gooder or liberator, but a true tyrant and oppressor. All he cared about was the interests of the masters, not the welfare of the people. ${ }^{86}$

It should be noted that in the early 20 th century, assessments of the 1812 war in the Lithuanian national and also historical discourse were influenced not only by historical periodicals in Russian. Some of the Lithuanian intelligentsia of noble origin whose Lithuanian national consciousness had formed under the influence of works about the historical past of the Grand Duchy of Lithuania, and who translated Słowacki's romantic poetry into Lithuanian, including works glorifying Napoleon, ${ }^{87}$ based their ideas on descriptions of military activity from 1812 that took place in the Vilnius province in Mickiewicz's poem Pan Tadeusz ..., ${ }^{88}$ and repeated the legendary words attributed to Napoleon about the beauty of St Anne's Church. ${ }^{89}$ However, this does not yet mean that the assessment of the 1812 war in these works served as a reason for the Lithuanian intelligentsia of noble origin to change the dominant interpretation in the Lithuanian historical narrative: the 1812 war foreign to Lithuanians as a site of the historical memory.

Attempts at presenting other assessments of the 1812 war in the Lithuanian national discourse were rare, fragmented, and often limited in terms of their coverage. For example, in 1885, Antanas Jurgelaitis, a correspondent for Lietuwiszkasis batsas (1885-1889), one of the most popular Lithuanian periodicals in New York, highlighted that the Lithuanians who were so eager to join $\mathrm{Na}-$ poleon's units believed they would be 'strongly defending their country, they would be doing a great service to all of Europe and the Poles' (... stiprei sawo kraszta gindami taptu didelei naudingais

${ }^{86}$ Ibid., p. 67 .

${ }^{87}$ Cf. see: K. Žegota [Kazys Puida], Iš sermégiaus krūtinès. Eilès (Vilnius, 19o6), pp. 91-92. Puida translated Słowacki's poem Na sprowadzenie prochów Napoleona (1840) into Lithuanian.

${ }^{88}$ Cf. M. Davainis-Silvestraitis, 'Iš Lietuvos. Glenboke (Dzišenų pav.)', Vilniaus žinios, 1 (14) May, No 108 (1905), p. 3.

${ }^{89}$ M. Davainis-Silvestraitis, 'Svarbios sukaktuvès', Vilniaus žinios, 18 (31) July 1907, No 95 (104), p. 1. 
del wisos Auropos ir Lenku)..$^{\circ}$ In his article Ka Napoleonas I apie Lietuva kalbējo [What Napoleon I said about Lithuania], Jurgelaitis stressed that Napoleon himself was very impressed by the courage of Lithuanian soldiers, and compared them to the 'Polish manor lords' who presided over the Lithuanian Provisional Governing Commission. According to Jurgelaitis, Napoleon supported the idea of Lithuanians' separation from the Poles, and the abolition of their union-based bonds, which revealed the intended message of the Lietuwiszkojo batso correspondent. For Jurgelaitis, the participation of Lithuanians in the 1812 war, and the words allegedly uttered by Napoleon, were one of the arguments accentuating the difference between the Lithuanian and Polish nations, the right of the Lithuanian nation to an ethnocultural existence separate from the Poles, and their political independence. Thus, it is no wonder that Jurgelaitis ended his article with an appeal to his audience: 'Dear Reader, show that wise person [Napoleon] respect and glory for knowing so clearly just who we are, and how we should exist. ${ }^{91}$

The Prussian-Lithuanian periodical press also stressed the courage of Lithuanians in Prussian army units; legendary stories were created about how Lithuanian soldiers almost took the French emperor himself captive in the Battle of Waterloo (18 June 1815). ${ }^{92}$ However, Prussian-Lithuanian publications from the late 19th and

\footnotetext{
${ }^{90}$ A. Jurgelaitis, 'Ka Napoleonas I apie Lietuva kalbējo', Lietuwiszkasis balsas, 22 December 1885, No 13, p. 51.

${ }^{91}$ Ibid.

${ }^{92}$ 'Lietuwininkai prie Waterloo mazne Napoleona sugauna', Tilžês Keleiwis, 19o6, No 5o, p. 1; 'Atsiminimai iš didžių česų', Tilžês Keleiwis, 1906, No 51, p. 3; Beweik sugautas, Lietuwißka Ceitunga, 1907, No 14, pp. 1-2; 'Lietuvei ir Napoleonas', Kaimynas, 1910, No 11, pp. 83-84. It should be noted that in the proclamation by the Prussian king of 1813 , which became a symbol of the beginning of its War of Liberation to rise up against the domination of France by Napoleon I, Lithuania was distinguished as a unique region. When inviting his subjects to rise up and fight, the king appealed to the populations of Brandenburg, Prussia, Silesia and Pomerania, and also made sure to mention Lithuania separately (using the invocation Lithuaer!). Cf. V. Safronovas, 'Lietuva vokiečių ir Prūsijos lietuvių erdvinèse sampratose', Lietuvos erdvinès sampratos ilgajame XIX šimtmetyje. Collection of articles, ed. D. Staliūnas (Vilnius, 2015), p. 267. The question remains open, however, as to how popular and to what extent this proclamation was heard in the Prussian Lithuanian community, and how much it affected assessments of the 1812 war.
} 
early 2oth centuries also featured a number of texts dedicated to the memory of the meetings between Queen Louise (Luise Auguste Wilhelmine Amalie) and Napoleon in Tilsit; ${ }^{93}$ she became a symbolic icon of the so-called War of Liberation (1813-1815), and embodied the dignity and fortitude of the Hohenzollern monarchy. The texts could have served the interests of those wanting to strengthen bonds with the German Empire and to shape their loyalty to the empire. The image of the empire's military might in the face of France, or more precisely, the Emperor Napoleon III, could also have encouraged stories about the Battle of Sedan (1 September 1870), which also appeared frequently in the Prussian-Lithuanian periodical press at the time. ${ }^{94}$

Antanas Macijauskas, one of the most active members of the Lithuanian community in Latvia, the president of Lithuanian societies and editor of the periodical Ryto garsas, attempted to analyse Lithuania's political situation as a part of the Russian Empire in a similar way to Maironis, in another version of the history of Lithuania, printed in 1910. Macijauskas stressed that, unlike later emperors of Russia, Alexander I supported science and culture, and supported the plans of Adam Jerzy Czartoryski, the chancellor of Vilnius University. ${ }^{95}$ But according to Macijauskas, such examples of the Russian Empire's 'indulgence' of Lithuania's interests was in fact brought about by the 1812 war, or more precisely, the 'invasion of Russia by the French in 1812 '. ${ }^{6}$ The author did not so much associate the spread of science and education in Lithuania with the reign of Alexander I but with Napoleon, who 'sowed the seeds of freedom all over Europe, the French brought with them the decrees of the great French Revolution; they became the instigators of science and enlightenment everywhere

93 'Karaliene Luyze bey Napoleons Tilžèje', Tilžês Keleiwis, No 3 (1888), pp. 13-15; 'Luizė Tilžeje', Tilžês Keleiwis, No 55 (1897), pp. 1-2; 'Napaleonas ir karaliene Luize', Lietuwißka Ceitunga, No 86 (1911), p. 2; 'Keli atsitikimai is Napaleono amžiaus', Kaimynas, No 5 (1911), pp. 39-40.

${ }^{94}$ 'Napoleons pas Sedana', Tilžês Keleiwis, No 32 (1908), pp. 1-2; 'Napaleonas prie Sedano', Lietuwißka Ceitunga, No 72 (1911), p. 3.

${ }^{95}$ [Antanas Macijauskas], Lengvuté Lietuvos istorija, parašė A. Agaras (Ryga, 1910), p. 71.

${ }^{96}$ Ibid. 
they went. ${ }^{97}$ It should be noted that one year later, in a history of Lithuania printed in 1911, Antanas Alekna stressed that 'in part of Lithuania, Suvalkija', where many figures in the Lithuanian national movement had come from, even after the Congress of Vienna, the 'decrees introduced' by Napoleon remained in place, and that he could still see their impact on the economic situation and cultural expression of Lithuanians to that very day. ${ }^{98}$ Nevertheless, these kinds of assessments of the 1812 war and its potential importance to Lithuanians remained one-off events in the Lithuanian national discourse of the early 2oth century, and their spread was limited.

The $\mathbf{1 8 1 2}$ war was viewed similarly as a foreign place of historical memory in the Belarusian national discourse in the early 2oth century. In Karotkaia gistoryia Belarusi (1910), the first history of Belarus to be written in the Belarusian language, the main teaching material for history lessons at illegal schools, it was stressed that only the Poles supported Napoleon. The 1812 war had brought serious economic hardship to 'the common folk': the 'French army's march on Moscow was accompanied by looting and fires. There were even cases of entire villages perishing from starvation after being plundered by the retreating French army. ${ }^{\prime 99}$ Thus, the 1812 war was not viewed so much as a war against an enemy, but as an episode that took place on territory inhabited by Belarusians. This type of assessment of the 1812 war was also continued in the main Belarusian nationalist periodical Nasha Niva. The main article to mark the 1ooth anniversary of the beginning of the 1812 war also stressed that

this war against the French brought many calamities on our land [...] the advancing French army looted villages; after each of their marches, entire villages would be left barren, wailing and crying could be heard from every peasant hut. ${ }^{100}$

The Belarusian intelligentsia interpreted the 1812 war as a Russian rather than a Belarusian war against Napoleon's army, sometimes adopting the term ' 20 nations' used in the Russian

\footnotetext{
${ }^{97}$ Ibid.

${ }_{98}^{8}$ [Antanas Alekna], Lietuvos istorija (Kaunas, 1911), p. 74.

${ }^{99}$ V. Lastouski, Karotkaia gistoryia Belarusi (Minsk, 1993), p. 95.

${ }^{100}$ '1812-1912', in: Nasha Niva, 5(18) studnia, No 1 (1912), p. 1.
} 
official discourse. ${ }^{101}$ As in the Lithuanian national discourse, the Belarusian equivalent also sometimes used the events of the 1812 war as 'a lesson in history': 'the events of this war show what an important role nations play. Nations die out when they do not evolve. Everyone must remember this, and we Belarusians have to know it. ${ }^{\prime 102}$ This is why, in the context of the 1ooth anniversary of the 1812 war, the Belarusian intelligentsia appealed to the national consciousness of Belarusians, accentuating the necessity of developing their national culture, which marks the strength and longevity of each nation.

\section{Conclusions}

The Russian government offered the population in the lands of the former GDL its official version of the historical memory of the 1812 war (a heroic battle against an invader), which contradicted the version this population considered as 'its own', experienced as their support for Napoleon and the new political and social prospects they believed he would bring. The censorship of written literature in suppressing the spread of the local historical memory was not so effective, due to the population's very limited opportunities to use the printed word. Communicative memory dominated in the land in the first half of the 19th century, becoming the main source testifying to and passing on to subsequent generations the actual multifaceted experiences of the 1812 war, including the chance of liberation from the yoke of Russia.

In the second half of the 19th century, the Russian government was still actively involved in the suppression of this alternate historical memory, resorting to censorship and the indoctrination of the world-view of young people, and later began to create the so-called regional narrative about the events of the 1812 war in the lands of the GDL. In response to the 1812 war as a Polish struggle for freedom and a symbol of political independence, members of local government structures and the local Russian intelligentsia (primarily teachers) explained in academic, educational and

\footnotetext{
${ }^{101}$ Ibid.

${ }^{102}$ Ibid.
} 
popular historical literature that the hopes the Poles attached to Napoleon were unfounded: the French emperor had no intention of ever restoring the former Polish-Lithuanian Commonwealth within its historical boundaries, but only to use Poles to supplement his army. It was stressed that only one section of local society fought to restore the former statehood of the lands of the GDL, the nobility, which represented Poles, and not Lithuanians or Belarusians at all. In turn, unlike Napoleon, the Russian Emperor Alexander I cared about the development and spread of Polish education and science, and was considering the idea of restoring Polish statehood. However, the Polish expression of support for Napoleon put an end to the Imperial Russian government's plans.

The so-called regional narrative that was applied in history textbooks and was used for emotional and visual impact in order to affect the younger generation's political and cultural provisions had two goals. First, to justify the discriminatory policies being implemented against people 'of Polish origin'. Second, to 'stop in its tracks' the use of the 1812 war as a historical argument testifying to the common historical past and the struggle endured by the Poles and Lithuanians, but also their possible political future, which was publicly expressed in the Polish national discourse in the early 2oth century. Over the course of a hundred years, regardless of the government's actions, the Poles managed to retain 'their own' historical memory about the 1812 war, whose meanings were spread via fiction, in museum exhibitions and in history textbooks, and were used to form the political and cultural position of the younger generation. Meanwhile, the Lithuanian and Belarusian national discourses viewed the 1812 war, as well as the 1830-1831 and 1863-1864 uprisings, as the concerns of the Poles and the Polonised nobility, and thus a foreign site of historical memory. In the early 2oth century, assessments of the 1812 war and its possible significance to Lithuanians were still only one-off, fragmented references in the Lithuanian national discourse, and their diffusion into broader society was limited. 
Author Details

Virgilijus Pugačiauskas is a researcher of 19th-century history at the Lithuanian Institute of History.

Address: Lithuanian Institute of History, 17 Tilto St, Vilnius LT-01101, Lithuania Email: virgilijus.pugaciauskas@istorija.lt

Olga Mastianica-Stankevič is a researcher of 19th-century history at the Lithuanian Institute of History.

Address: Lithuanian Institute of History, 17 Tilto St, Vilnius LT-01101, Lithuania ORCID: oooo-ooo3-3094-3539

Email: mastianica@gmail.com

\section{Bibliography}

'1812-1912', in: Nasha Niva, 1912, 5(18) studnia, No 1, p. 1.

AIDUKAITÉ, Deimantè. 'Didžiojo prancūzų karvedžio atgarsiai Pietų Lietuvoje', in: http://gintarinesvajone.lt/2013/o5/13/didziojo-prancuzu-karvedzio-atgarsiai-pietu-lietuvoje/ (accessed 2021 o6 7).

Akty i dokumenty arkhiva Vilenskogo, Kovenskogo i Grodnenskogo general-gubernatorskogo upravleniia, otnosiashchiesia k istorii 1812-1813 gg. Chast pervaia. Perepiska po voennoi chasti (Vilna, 1912).

Akty i dokumenty arkhiva Vilenskogo, Kovenskogo i Grodnenskogo general-gubernatorskogo upravlenüa, otnosiashchiesia k istorii 1812-1813 gg. Chast vtoraia. Perepiska po chasti grazdanskogo upravleniia (Vilna, 1912).

Akty, dokumenty i materialy dlia politicheskoi i bytovoi istorii 1812 goda, sobrannyie i izdannyie po porucheniu ego imperatorskogo velichestva velikogo kniazia Mikhaila Aleksandrovicha, pod redaktsiei K. Voenskogo. Tom pervyi (St Petersburg, 1909).

AMBROZAITIS J. 'Prancūzkapiai', in: Karys, No 33 (1930), p. 652.

[ALEKNA, Antanas]. Lietuvos istorija. Parašè kun. A. Alekna 'Vienybès' redaktorius (Kaunas, 1911).

'Atsiminimai iš didžių česų', in: Tilžês Keleiwis, No 51 (1906), p. 3.

BAIRAŠAUSKAITÉ, Tamara. Mykolas Juozapas Römeris (1778-1853): bajoro viešoji ir privati erdvès XIX a. pirmojoje pusèje (Vilnius, 2011).

BALIŃSKI, Michał. Opisanie statystyczne miasta Wilna (Wilno, 1835).

BASANAVIČIUS, Jonas. Rinktiniai raštai (Vilnius, 1970).

'Beweik sugautas', in: Lietuwißka Ceitunga, No 14 (1907), pp. 1-2.

BIRŽIŠKA, Mykolas. Dainu atsiminimai iš Lietuvos istorijos (Vilnius, 1920).

BERNATSKII, Nikolai. Sobytiia v Vil'ne vo vremia Otechestvennoi voiny. Izdanie Vilenskogo kruzhka revnitelei pamiati stariny 12 goda (Vil’na, 1912). 
BOCHKOV, Evgenii. V interesakh podderzhaniia nashikh serdechnykh otnoshenii s Frantsiei. Uchastie francuzskikh delegatsii v merompriatiakh, posviashchionnykh stoletiiu Borodinskogo srazheniia, Peterburgskii istoricheskii zhurnal, No 2 (2017), pp. 232-255.

BULGANOV, Aleksandr, VANDALKOVSKAIA, Mariia, SIDOROVA, Liudmila, SOKOLOVA, Aleksandra. Istoricheskaia pamiat russkogo naroda ob Otechestvennoi voinie 1812 goda (Tula, 2012).

DĄBROWSKI, Przemysław. Narodowa Demokracja bytego Wielkiego Księstwa Litewskiego. Studium z zakresu myśli politycznej i dziatalności obozu narodowego na ziemiach litewsko-biatoruskich w latach 1897-1918 (Kraków, 2010).

DAVAINIS-SILVESTRAITIS, Mečislovas. 'Iš Lietuvos. Glenboke (Dzišenu pav.)', in: Vilniaus žinios, 1(14) May 1905, No 108, p. 3.

DAVAINIS-SILVESTRAITIS, Mečislovas. 'Svarbios sukaktuvės', Vilniaus žinios, 18(31) July, 1907, No 95 (104), p. 1.

Die Napoleonischen Kriege in der europäischen Erinnerung, hg. Caroline Klausing, Verena von Wiczlinski (Biefeld, 2017).

DUNDULIS, Bronius. Lietuva Napoleono agresijos metais (1807-1812) (Vilnius, 1981).

DUNDULIS, Bronius. Napoléon et la Lituanie en 1812 (Paris, 1940).

FAJNHAUZ, Dawid. 1863 Litwa i Biatoruś (Warszawa, 1999).

FEDORENKO, V [?], 'O predostavlenii mesta dla sooruzheniia pamiatnika pogibshim v 1812 godu', in: Vilenskii voennyi listok, 4 March, No 614 (1912), p. 4.

'Frantsuzkii pamiatnik v Vil'ne', in: Vilenskii vestnik, 2 March, No 2612 (1912), p. 3 .

GIEDA, Aurelijus. 'Maironio istoriko fenomenas'. Maironio balsai. Küryba, veikla, atmintis, ed. M. Žvirgždas (Vilnius, 2019), pp. 376-408.

GOŠTAUTAS, Jonas. Ponas teisëjaitis arba pasakojimas apie Lietuva ir Žemaitija, ed. K. Korsakas (Vilnius, 1967).

GRIŠKAITĖ, Reda. 'Vilniaus laikinosios archeologijos komisijos „,neakivaizdininkès": ,gender aspektas" Vilniaus senienų muziejaus istorijoje (1856-1865)', in: Kova dèl Istorijos: Vilniaus senienu muziejus (1855-1915): mokslo straipsniu rinkinys, eds. R. Griškaitè, Ž. Būčys (Vilnius, 2015).

ILOVAISKII, Dmitrii. Kratkie ocherki russkoi istorii. Kurs starshego vozrasta. 9-oie izdanie (Moskva, 1868).

IWASZKIEWICZ, Janusz. 'Litwa w przededniu wielkiej wojny 1812 roku', Biblioteka warszawska, Vol. 4 (1906), pp. 435-465.

JUKNEVIČIUS, Petras. 'Napoleonas Panevéžio kašte, Iš mūsų krašto praeities', Tëryné, No 13 (6387) (2006).

JURGELAITIS, Antanas. 'Ka Napoleonas I apie Lietuva kalbējo', Lietuwiszkasis balsas, 22 December 1885, No 13, p. 51. 
JUŠKA, Antanas. Lietuviškos dainos, Vol. 1 (Vilnius, 1954).

'Karaliene Luyze bey Napoleons Tilžèje', in: Tilžês Keleiwis, 1888, No 3, pp. 13-15.

Karta voiny 1812 goda ot Nemana do Moskvy. Sostavil general’nogo shtaba polkovnik [Sergei] Tomilin. 2-izdanie Vilenskogo kruzhka revnitelei pamiati stariny 12-goda (Vilna, 1912).

'Keli atsitikimai is Napaleono amžiaus', in: Kaimynas, 1911, No 5, pp. 39-40.

KERBELYTĖ, Bronislava. Lietuviu liaudies padavimai (Vilnius, 1970).

KIRKOR, Adam Honory. Przechadzki po Wilnie i jego okolicach (Wilno, 1880).

KRIKŠTOPAITYTĖ, Danutè. Lietuviu liaudies karinès-istorinès dainos (Vilnius, 1965).

'Kronika. Vilniuje. Prancūzų karo jubiliejus', in: Viltis, 24 August 1912, No 100 (735), p. 2.

KUDRINSKII, Fedot. Otechestvennaia voina 1812 goda (s 10 risunkami $v$ tekste), (Vilna, 1912).

LASTOUSKI, Vaclau. Karotkaia gistoryia Belarusi (Minsk, 1993).

'Lietuvei ir Napoleonas', in: Kaimynas, No 11 (1910), pp. 83-84.

Lietuvos TSR šaltiniai, Vol. 1 (Vilnius, 1955).

'Lietuwininkai prie Waterloo mazne Napoleona sugauna', in: Tilžês Keleiwis, No 50 (1906), p. 1.

LEISEROWITZ, Ruth. 'Heldenhaften Zeiten. Die polnische Erinnerungen an die Revolutions-und Napoleonischen Kriege 1815-1945', Band 4: Die Revolutions-und Napoleonishen Kriege in der europäischen Erinnerung (Biefeld, 2017).

LOBAČIUS, Uladzimeras. 'Archeologiniai paminklai tradiciniame liaudies pasaulèvaizdyje (Baltarusijos-Rusijos paribys)', in: Liaudies kultūra, No 5 (2015), pp. 47-52.

'Luizė Tilžèje', in: Tilžês Keleiwis, No 55 (1897), pp. 1-2.

[MACIJAUSKAS, Antanas]. Lengvute Lietuvos istorija, parašè A. Agaras (Ryga, 1910).

[MAIRONIS]. Lietuvos istorija su kunigaikščiu paveikslais ir žemlapiu. Parašė Maironis (Š.M-lis). Trečią kartą atspausta ir partaisyta. 19o6. Išleista Lietuvių laikraščio pinigais (Petropilis, 1906).

MEDIŠAUSKIENĖ, Zita. Rusijos cenzūra Lietuvoje XIX a. viduryje (Kaunas, 1998).

MIKHAILOVA, Yulia. 'Formirovanie istoricheskoi pamiati o voinie 1812 g. u latyshei v seredine XIX - nachale XX vv., in: Elektronnyi nauchnoobrazovatelnyi zhurnal „Istoriia', 2020, vypusk 4 (90), Vol. 11.

'Napaleonas ir karaliene Luize', in: Lietuwißka Ceitunga, No 86 (1911), p. 2 . 
'Napaleonas prie Sedano', Lietuwißka Ceitunga, No 72 (1911), p. 3.

Napoleonowi: 1812-1912 (wojny napoleonowskie a Litwa) (Warszawa [1912]).

'Napoleons pas Sedana', in: Tilžês Keleiwis, No 32 (1908), pp. 1-2.

NARUNEC, Romuald. Michat Baliński jako mecenas polsko-litewskich więzi kulturowych (Warszawa, 1995).

NAZAROVA, Ievgeniia. 'Chtenie dlia latyshei o voinie 1812 g. XIX nachalo XX vv.', in: Rossiia i Baltiia: vyp. 7. Pamiatnyie daty i istoricheskaia pamiat (Moskva, 2015), pp. 81-107.

OBST, Jan. 'Przedmowa. Rok 1812 na Litwie', in: Litwa i Ruś. Miesięcznik ilustrowany, poświęcony kulturze, dziejom, krajoznawstwu i ludoznawstwu. Maj-czerwiec, Vol. II, z. II/III (1912), pp. 66-70.

[OBST, Jan], J.O. 'O naszą przeszłość', in: Dziennik Wileński, 1918, 13 XI, p. 1. PAVLENKO, Viktoriia. 'O podgotovke prazdnovaniia 10o-letnego iubilieia voiny 1812 goda v Vilenskoi i Varshavskoi guberniakh', in: Arkheigraficheskii ezhegodnik za 2012 god (Moskva, 2016), pp. 145-152.

POCHODAJ, Andrzej. Legenda Napaleona I Bonaparte w kulturze polskiego romantyzmu (Wrocław, 2002).

[POGODIN, Aleksandr]. 'Napoleon i Litva', in: Otechestvennaia voina i russkoe obshchestvo, 1812-1912, Vol. III (Moskva, 1911), pp. 162-169.

POŠKA, Dionizas. Raštai (Vilnius, 1959).

Prazdovanie 1oo-letnego iubelieia Otechestvennoi voiny $v$ Vilenskom uchebnom okruge. Sostavil i.o. inspektora Vilenskogo realnogo uchilishcha A.P. Belkovskii (Vilna 1913).

'Prebyvanie frantsuzkogo voennogo agenta v Vi'lne', in: Vilenskii voennyi listok, 1912, 2 maja, No 626, p. 3.

PUGAČIAUSKAS, Virgilijus. XIX a. Lietuvos kariniu daliniu istorija (Vilnius, 2019).

[PUIDA, Kazys]. Iš sermégiaus krūtinès. Eilès (Vilnius, 1906).

PUZYNINA, Gabriela. W Wilnie $i w$ dworach Litewskich: pamiętnik $z$ lat 1815-1843 (Wilno, 1928).

R. M. [?]. 'Napoleono nepasisekimas', in: Kauno kalendorius 1915 metams. Šv. Kazimiero draugijos leidinys (Kaunas, 1914), pp. 47-49.

ROMER-OCHENKOWSKA, Helena. $Z$ dziejów tajnej oświaty $w$ Wilnie i Wileńszczyźnie, Nasza walka o szkotę polska 1901-1917. Opracowania, wspomnienia, dokumenty. Vol. II (Warszawa, 1934).

Różne Wiadomości. (Nadesłane.) Z listu zacnej Litwinki, Ojczyzna: dziennik polityczny, literacki i naukowy. 1864, No 38 .

SABUROVA, Tatiana. "The Patriotic War of 1812 in the Commemorative Practices and Historical Memory of Russian Society from the Nineteenth 
to the Early Twenty-First Centuries', in: Russia and the Napoleonic Wars eds. J.M. Hartley, P. Keenan, D. Lieven (London, 2015), pp. 243-257.

SAFRONOVAS, Vasilijus. 'Lietuva vokiečių ir Prūsijos lietuvių erdvinėse sampratose', Lietuvos erdvinès sampratos ilgajame XIX šimtmetyje. Collection of articles, ed. D. Staliūnas (Vilnius, 2015), pp. 263-297.

SCHIMSCHEIMER, Christof. 'Ein Beispiel gab uns Bonaparte?" Die Napoleonische Kriege in der kolektiven Erinnerung der Polen', Die Napoleonischen Kriege in der europäischen Erinnering (Bielfield, 2017), pp. $65^{-101 .}$

Senis Betgyvas [?]. 'Prie D-ro Noraus sumanymo', Vilniaus žinios, 21 April (4 May) 1905, No 99, p. 1.

SLIESORIŪNAS, Feliksas, KRUOPAS, Jonas. 'Nežinomas $1831 \mathrm{~m}$. Lietuvos sukilèlių atsišaukimas lietuvių kalba', in: Lietuvos TSR Mokslu akademijos darbai, serija A, Vol. 1 (18), (1965), pp. 239-243.

SLIESORIŪNAS, Feliksas. 'Klasiniai prieštaravimai 1830-1831 metu sukilime', in: Lietuvos TSR Mokslu akademijos darbai, serija A, Vol. 1 (18), (1965), pp. 85-107.

STALIŪNAS, Darius. Savas ar svetimas paveldas? 1863-1864 m. sukilimas kaip lietuviu atminties vieta (Vilnius, 2008).

TIŠKEVIČIUS, Konstantinas. Neris ir jos krantai: hidrografiniu, istoriniu, archeologiniu ir etnografiniu požiūriu, ed. R. Griškaitè (Vilnius, 2013).

[TURTSEVICH, Arsenii]. Chrestomatia po istorii Zapadnoi Rosii. Uchebnoe posobie dlia uchenikov starshikh klassov srednikh uchebnykh zavednii. Sostavil Ar[senii] Turtsevich, prepodavatel Vilenskoi pervoi gimnazii $i$ Vilenskoi rimsk.-kat. duchovnoi seminarii (Vilna, 1892).

ULIANOVA, Galina. 'Iubilei Borodinskoi bitvy i problema transformatsii istoricheskoi pamiati: istoriografia i periodizatsiia', in: Epokha 1812 goda $v$ sudbakh Rosii i Evropy, Materialy mezdunarodnoi nauchnoi konferentsii (Moskva, 8-11 oktiabria 2012 g.), sost. G.N. Bibikov, L.V. Mel'nikova (Moskva, 2013), pp. 498-509.

[UNTULIS, Matas]. 'Napoleonas', Vilniaus kalendorius 1913 metams (Vilnius, 1912), pp. 63-69.

[VALIOKAITIS, Juozas], Skrebenis. 'Mųsų paveikslai. Įveiktas vadas', Šaltinis, 12 December (29 November) No 37 (1906), p. 585.

VANAGAS, Vytautas. Antanas Strazdas (Vilnius, 1968).

ZAHORSKI, Andrzej. Z dziejów legendy napoleońskiej w Polsce (Warszawa, 1971).

ŻYCKA, Ludwika. Krótki rys dziejów tajnej oświaty polskiej na ziemi Wileńskiej od 1880 do 1919 (Wilno, 1932). 


\title{
1812 M. KARO ISTORINE ATMINTIS LIETUVOJE XIX-XX A. PRADŽIOJE: KOMPLIKUOTAS PROCESAS
}

\author{
Santrauka \\ VIRGILIJUS PUGAČIAUSKAS, OLGA MASTIANICA-STANKEVIČ
}

Napoleono karų atminimo kultūros istoriografijoje nemažai dėmesio skiriama 1812 m. Prancūzijos-Rusijos karo atminties kultūros problemoms. Tačiau Lietuvos atvejis atskirai nèra nagrinètas. Šio straipsnio tikslas - išanalizuoti, kaip $1812 \mathrm{~m}$. karo vertinimai Lietuvoje buvo palaikomi ir evoliucionavo istorinëje atmintyje.

Rusijos valdžia buvusios LDK žemių gyventojams siūlè oficialią $1812 \mathrm{~m}$. karo istorinės atminties versiją (didvyriškos kovos su užkariautoju), kuri prieštaravo vietinei „savajai“, liudijančiai patirtis, susijusias su parama Napoleonui ir naujomis krašto politinėmis bei socialinėmis perspektyvomis. Rašytinès literatūros cenzūros siekis slopinti vietinės istorinès atminties sklaidą nebuvo veiksmingas dèl gyventojų itin menku galimybiu naudotis spausdintu žodžiu. XIX a. pirmoje pusejje krašte dominavo komunikacinè atmintis, kuri tapo atraminiu šaltiniu, liudijančiu ir perduodančiu naujoms kartoms $1812 \mathrm{~m}$. karo tikrąsias daugialypes patirtis, tarp jų - galimybes išsilaisvinti iš Rusijos imperijos.

XIX a. antroje pusėje Rusijos imperijos vietinės valdžios struktūrų atstovai, vietinė rusų inteligentija, atsižvelgdama ị $1812 \mathrm{~m}$. karo, kaip lenkų kovos už laisvę, politini savarankiškumą, simbolį, akademinejje, mokomojoje ir populiariojoje literatūroje aiškino, kad lenkų viltys, sietos su Napoleonu, buvo nepagrịstos: Prancūzijos imperatorius neturẻjo tikslų atkurti buvusią Abiejų Tautų Respubliką istorinėse ribose, jis siekè vien papildyti lenkais savo kariuomenės dalinius. Buvo pabrèžiama, kad lenku reikštas Napoleono palaikymas sustabdė Rusijos imperijos valdžios galimus planus atkurti buvusi lenkų valstybingumą. Šis vadinamasis regioninis pasakojimas, kuris buvo skelbiamas istorijos vadovèliuose, naudotas emocinio ir vizualaus poveikio priemonėse siekiant paveikti jaunosios kartos politines ir kultūrines nuostatas, turejjo dvejopus tikslus. Pirma, pateisinti vykdomą diskriminacinę politiką prieš „lenku kilmės“ asmenis. Antra, „užkirsti kelią“ naudoti $1812 \mathrm{~m}$. karą kaip istorinį argumentą, bylojantį ne vien apie bendrą lenkų ir lietuvių istorinę praeiti ir kovą, bet ir galimą politinę ateiti, kuris viešai reikštas XX a. pradžios lenkų tautiniame diskurse.

Per šimtą metų lenkai, nepaisydami valdžios veiksmų, sugebẻjo išlaikyti „savająa" istorinę $1812 \mathrm{~m}$. karo atmintį, kurios reikšmès buvo medijuojamos grožinèje literatūroje, muziejų ekspozicijose, istorijos vadovèliuose, naudotos formuojant jaunosios kartos politines ir kultūrines nuostatas. O lietuvių tautiniame diskurse $1812 \mathrm{~m}$. karas, kaip ir 1830-1831 m. bei 1863-1864 m. sukilimai, vertintas kaip lenkų ir sulenkejjusių bajorų reikalas, svetima istorinės atminties vieta. $1812 \mathrm{~m}$. karo, jo galimos svarbos lietuviams vertinimai XX a. pradžios lietuvių tautiniame diskurse buvo pavieniai, fragmentuoti, o jų sklaida platesniems visuomenès sluoksniams menka. 